\title{
National Labor Movements and Transnational Connections: Global Labor's Evolving Architecture Under Neoliberalism ${ }^{1}$
}

\author{
Peter Evans, University of California, Berkeley \\ and Watson Institute, Brown University
}

\begin{abstract}
The neoliberal era has undermined worker's rights and labor's power at the national level, but has also been characterized as an era of 'the new labor transnationalism'. Shifting fortunes at the national level have been fundamental to expanding openness to transnational alliances. An analysis of campaigns connecting U.S. labor to the Honduran CGT, the Bridgestone-Firestone workers in Liberia, the Gerdau Workers World Council, and other national unions in both North and South show how adversity at the national level has pushed U.S. labor toward transnational alliances. Conversely, the growing global role of major countries in the South has expanded their potential contribution to transnational alliances, as illustrated by Brazilian labor's involvement with both European unions like the Dutch FNV and U.S. unions like the UAW and the USW. New connections among national labor movements are complemented by the expansion of Global Union Federations and new governance instruments like Global Framework Agreements, which articulate multi-country connections. Assessing the connections among national labor movements and the new global organizational infrastructure that have emerged under neoliberalism is a necessary foundation for building better theories of labor's evolving contestation with global capital.
\end{abstract}

\section{KEYWORDS}

Brazil global unions, labor transnationalism, national labor movements, neoliberalism.

Evangelina Argueta and her fellow apparel organizers from the Honduran Central General de Trabajadores (CGT) confounded the conventional vision of low-wage workers as powerless victims by forcing the giant U.S.-based Russell Athletics to negotiate a contract in 2010. As Argueta put it, 'Business leaders in Honduras still perpetuate the myth that in this country - and particularly in the maquila industry - it is impossible to organize, and that under no circumstances will unions be tolerated. This is why the Russell victory is so important. It proves that it is possible to organize in the maquilas' (MSN, 2010).

The struggle to organize Russell was forged through decades of tireless work in Honduras by organizers like Argueta, but it was also a victory for transnational organizing, made possible by a cross-regional network of labor Non-Governmental Organizations (NGOs) and unions that connected Honduras and the United States. Cases like this make evident the possibility of building labor's collective agency by linking disparate national terrains. 
While Honduras might seem an unlikely place to start looking for trends in global organizing, many would consider the Russell case an exemplar of what is often called the 'new labor transnationalism'. Efforts to document and explain the emergence of a 'new labor internationalism' started to proliferate at the turn of the millennium, part of the general surge of post-Seattle optimism (e.g. Mazur, 2000; Munck, 2002; Waterman, 2001) In general, explanations focused on opportunities and incentives created by the emergence of a more globalized political economy. ${ }^{2}$

The general conditions created by neoliberal globalization are certainly key to labor's fortunes. Yet, national labor movements are still the most important components of the global labor movement, and the overall architecture of global labor solidarity depends on how national strategies fit together. Potential fit depends in turn on the evolving characteristics of the political terrains that labor faces in each national context. Can national labor movements take advantage of the differences among the local terrains on which they operate rather than allowing difference to undermine solidarity? How do changing national fortunes affect the openness of national labor movements to transnational alliances?

The literature that speaks to these questions remains underdeveloped. With some notable exceptions (e.g. Anner, 2011; McCallum, 2013), there are relatively few studies of the global labor movement under neoliberalism that highlight the evolution of interactions among national labor movements. Broad historical comparative analyses (e.g. Silver, 2003) are more likely to highlight the ways in which the shifting geography of global production affects mobilization in different countries than to focus on connections among national labor movements. Studies of the dynamics of global campaigns (e.g. Bronfenbrenner, 2007) highlight cross border connections but usually do not present arguments about how political trajectories at the national level feed into their success or failure.

Analysis of the effects of national context has been most likely to focus on how being located in a privileged national economy undermines labor transnationalism. Studies documenting labor's complicity in the designs of American imperialism are one example (e.g. Scipes, 2010). There is also no dearth of analyses of how the promise of local political privilege sucks labor movements in the Global South into nationalist coalitions dominated by capital, undercutting broader projects of working class solidarity (e.g. Chibber, 2007). That national roots can have negative effects on labor transnationalism, particularly when they confer privilege, goes without saying. But, a balanced analysis should also examine possibilities of positive synergies among differently situated national labor movements.

\section{National Connections and Labor Transnationalism}

Exploring the ways in which national differences might translate into positive synergies conducive to labor transnationalism is the aim of this article. It is also a response to the conundrum of why examples of a new labor transnationalism should proliferate under the aegis of neoliberalism, a geopolitical regime implacably hostile to labor. ${ }^{3}$

The decline of labor's political power at the national level, along with its ability to deliver economic benefits to its members, is one of the most salient features of the neoliberal era. Union densities fell (especially in the North); anti-union legislation flourished (particularly in the United States); precarity increased (in both North and South) (see Standing, 2011). Yet, despite the misfortunes of labor at the national level, new connections among national labor movements and new forms of global labor organization facilitating such connections continued to emerge. 
Explicating the structural changes and strategies that have facilitated labor's ability to use national differences synergistically complements global explanations of the new labor transnationalism and balances arguments that see the consequences of national differences in overwhelmingly negative terms. It also helps explain why analysts find new instances of labor transnationalism in the midst of such an adverse climate. My analysis will focus on two structural shifts that have facilitated the synergistic use of national differences and on changes in labor strategy at the global level that have facilitated connecting movements across national borders.

First, I will argue that fierce attacks on labor, which are integral to the decline of the U.S. national economy, have stimulated the emergence of new transnational perspectives and strategies in the U.S. labor movement. If a shift from ascending national hegemony to declining national hegemony in the U.S. has stimulated interest in cross border alliances, this is a potentially significant shift in the possibilities for labor transnationalism. However beleaguered, the U.S. labor movement still commands vastly greater resources than most labor movements in the Global South.

A second, complementary, structural shift, which has been dubbed 'the rise of the South' (see UNDP, 2013), has increased the ability of labor movements in at least some major countries of the Global South to extend their vision and reach beyond their national borders. The thoroughly globalized character of the capital that these labor movements confront on their own national terrain is an important stimulus to transnationalism. The capacity to act on these incentives depends on both internal organizational strength and labor's political position at the national level. Brazilian labor's transnational alliances are the best twenty-first century example of the transnationalism that this shift makes possible.

The development of organization and strategy at the global level has complemented these two structural shifts in national positions, making it easier for labor to coordinate actions across multiple national terrains. More aggressive and better-organized efforts by Global Union Federations (GUFs) can facilitate the integration of the institution-building strategies traditionally associated with European unions with the aggressive cross-border corporate campaigns associated with U.S. unions (see Bronfenbrenner, 2007). At the same time, the burgeoning of Global Framework Agreements (GFAs) provide new instruments through which labor could begin trying to construct its own version of global governance (see McCallum, 2013). These developments at the global level depend on engagement from national labor movements to make them work, but also help make such engagement more likely.

The body of the analysis has three sections, the first two focusing on the effects of structural shifts in national fortunes and the third on complementary global changes. In the first section, I will start by looking at a variety of international campaigns that involve the U.S. unions. They range from 'anti-sweatshop' campaigns in the apparel industry to the cross-border alliances of the United Steelworkers (USW) to the current efforts of the United Auto Workers (UAW) to transnationalize its organizing efforts in the auto industry. This section shows how openness to transnational solidarity on the part of U.S. unions can facilitate the struggles of local unions in small countries like Honduras and Liberia. At the same time, it shows how major countries in the Global South like Brazil can become strategically important allies for unions in the North.

The second section focuses on the promise created by the growth of labor movements in the Global South, using Brazil as the primary example. Brazil offers a window on evolving strategies and organizational forms in the global labor movement. Brazil's extensive involvement in European-style worldwide works councils, enterprise networks and International (or Global) Framework agreements (IFAs or GFAs) complements its involvement in U.S. style campaigns, including campaigns organized by the UAW and the USW. 
The third section shows how the same institutional innovations that the Brazilian labor movement has found useful have facilitated multi-country organizing efforts. This section highlights the interaction of national and global unions in the campaign to organize Group 4 Securicor (G4S) security guards, as described by McCallum (2013). Built on new organizational ties between Union Network International (UNI), a Global Union with roots in Europe, and the Service Employees International Union (SEIU), one of the foremost practitioners of U.S.-style campaigns, the G4S campaign combined a European-style Global Framework Agreement with an aggressive corporate campaign that included on-the-ground mobilization in a range of countries. McCallum's analysis of the campaign's dynamics in India and South Africa reinforces the importance of national political context while illustrating in the South African case how a global campaign can contribute to union revitalization at the national level.

The concluding section turns to the question of how far we can generalize from the specific cases reviewed in the three proceeding sections and what their implications for the future might be. Are the sorts of synergistic connections between national labor movements analyzed here ephemeral or are likely to persist and spread? How significant and robust are their effects on the overall architecture of the global labor movement? How vulnerable are they to being undercut by future changes in the structure of the global political economy?

\section{A New Transnationalism in the 'Belly of the Beast'?"}

Current transnational initiatives by U.S. unions must surmount the resentment and skepticism generated by U.S. labor's complicity in the suppression of militant labor organizations around the world during the heyday of imperial hubris (see Scipes, 2010). Nonetheless, examined in their own right, new transnational initiatives involving U.S. unions appear to reflect a significant shift in attitudes towards the value of building alliances with other national labor movements.

Both the decline of the U.S. domestic economy and the changing domestic political terrain associated with neoliberalism helped stimulate U.S. labor's receptiveness to transnational strategies. By the early 1990's, when the Clinton administration, labor's supposed political ally, demonstrated its unrelenting support for global capital's version of internationalism by forcing the North American Free Trade Agreement (NAFTA) through congress (Kay, 2010), it was clear that the political foundations of a nationalist strategy were gone. Bipartisan subservience to corporate priorities turned dreams of nationalist protection into chimeras. At the same time, neoliberalism reinforced capital's aggressiveness within the U.S., making it clear that without new strategies the U.S. labor movement would shrivel.

My illustrative sampling of new initiatives that emerged under neoliberalism begins with the Russell Athletics campaign, the apogee of transnational anti-sweatshop activism. A discussion of new international initiatives by two classic U.S. industrial unions - the USW and UAW - follows. In addition to making the case for a 'new transnationalism' in the U.S. labor movement, the section illustrates two different sorts of 'reverse whipsawing." On the one hand, U.S. internationalism offers useful support for workers in Honduras and Liberia. On the other hand, alliances with the more politically secure Brazilian labor movement provide strategic help to beleaguered U.S. unions.

In campaigns like Russell, the emergence of new organizational actors like United Students Against Sweatshops (USAS) and the Workers Rights Consortium (WRC) was crucial to turning sweatshops into targets, but support from traditional unions was integral to these campaigns (Rodriguez, 2007). From the historical role of Union of Needletrades, Industrial and Textile Employees (UNITE) in the emergence of USAS to the crucial role of Jeff Hermanson ${ }^{6}$ in the Russell 
negotiations, there was symbiosis between organizers working for traditional unions and activists connected to new organizations. And, unlike many transnational NGO ventures (see Seidman, 2007), anti-sweatshop campaigns like the one against Russell are 'in alliance with' rather than 'on behalf of insurgent workers in the South, who define their struggles in terms of union demands recognition, collective bargaining, decent wages, dignified work and protection from management reprisals.

The 2010 Russell victory described by Evangelina Argueta (above) had already been recognized as the 'biggest victory by far' for organizers of apparel sweatshops (Greenhouse, 2009) and as 'the most sweeping labor agreement that manufacturing in Central America has ever seen' (Graham, 2010). One of the largest U.S. apparel producers and largest single employer in Honduras's most important export industry, Russell had never signed a contract with any union during its 100 years of operation in the U.S. ${ }^{7}$ The 2010 agreement included re-employment for 1,200 apparel workers in a new unionized enterprise (Jerzees Nuevo Dia), a pledge of neutrality by Russell and access for organizers to their other factories in Honduras, which employed circa 10,000 workers.

The victory depended on the felicitous convergence of several factors that made Russell vulnerable - from its reliance on directly owned production in Central American to it reliance on the university apparel niche in the United States. Even more important, it depended on a reservoir of accumulated strategic acumen distributed through the transnational network of labor organizations. ${ }^{8}$

At first glance, Honduras was an unlikely terrain for a $21^{\text {st }}$ century organizing triumph. Business domination of the Honduran state persisted even during the populist regime of Mel Zelaya. The 2009 military coup overthrowing Zelaya reinforced an atmosphere of repression in which violence against labor activists was rife. The business elite was permeated by traditional anticommunist ideology in which unions and communism often went undistinguished.

On closer examination, Honduras was a more favorable site for organizing than it appeared. Labor militancy was a long established tradition. Indomitable organizers like Argueta operated within this repressive environment with surprising effectiveness. Honduran labor law, a relic of earlier times in which good labor law was considered a sign of 'modernity,' was quite progressive. Enforcement was laughable but having laws on the books was still an advantage, given that codes of conduct in the United States required conformity with local labor laws. Honduran apparel manufacturers, both domestic and foreign-owned, were closely tied to U.S. markets and therefore vulnerable to threats in these markets.

Strong local labor militancy and elite dependence on U.S. markets created potential for a transnational alliance. When the Honduran workers made a strategic decision to build ties with transnational allies, there was a structure in place to which they could connect (see Anner, 2013: 31). They connected to an anti-sweatshop architecture that was far from perfect. The Fair Labor Association, whose mission in theory was persuading U.S. manufacturers to comply with codes of conduct, at first dismissed the Honduran workers' claims (Anner, 2013: 32). Despite this, USAS was successful in threatening Russell's lucrative university apparel markets. By the time of the settlement, approximately 110 universities had ended their contracts with Russell and USAS had begun to go after Russell's major non-university customers (see Anner, 2013: 34). The final victory was a transnational product that leveraged institutional resources in Russell's U.S. home base to compensate for recalcitrant local managers and the lack of reliable state enforcement in Honduras. CGT representatives came to the U.S. to involve Russell's headquarters management in the final negotiations. The final agreement is enforceable through binding arbitration in the United States. 
The Russell case is exceptional but not unique. The successful struggle to form an independent union on Bridgestone-Firestone's Liberian rubber plantations is a variation on the use of U.S.-based organizational resources to put pressure on the foreign operations of a U.S. corporation in a small, poor country. Conditions on the plantations were so execrable that the International Labor Rights Forum (ILRF) sued Bridgestone-Firestone in 2005 for imposing 'slavelike working conditions' (see ILRF, 2005). The USW, which organizes the U.S. workers of Bridgestone-Firestone, had its own problems with the company and saw a chance to put Firestone on the defensive. When plantation workers went on a wildcat strike, USW Bridgestone-Firestone locals in the United States collected support funds for the striking workers. Later, when the newly formed Firestone Agricultural Workers Union of Liberia (FAWUL) fought an election against the Firestone plantation's established yellow union, the USW, ICEM (International Federation of Chemical, Energy, Mine and General Workers' Unions), and the AFL-CIO (American Federation of Labor/Congress of Industrial Organizations) Solidarity Center provided support and FAWUL won the internationally monitored election (Kazdin, 2012). In this case, support from U.S. allies was less fundamental than in the Russell case, in part because the newly elected government of Ellen Johnson Sirleaf was supportive of the Firestone workers, but the formation of an independent union with 5,000 members in the country's most crucial export sector was as momentous as the Russell victory.

The Honduran and Liberian cases demonstrated that, under neoliberalism, militant workers in small, poor countries economically dependent on the U.S. could leverage transnational connections with U.S. labor. Such transnational alliances help change national terrains. The local labor movements they invigorated have new potential to become local political actors.

These cases illustrate an openness to transnational alliances in U.S. unions whose origins lie in tradable goods industries, where conflicts over the geographic location of jobs have traditionally been considered a barrier to building North-South solidarity (Evans, 2010: 355). They are equally interesting because they are built on alliances between traditional unions and the new labor NGO's, whose organizational style and ideology are sometime portrayed as being at odds with traditional unionism, suggesting that cross-national connections and connections that bridge organizational types may be synergistically related (see Anner and Evans, 2004).

Unfortunately, only a limited number of countries fit the profile of Honduras and Liberia. Victories in the countries that do fit, even if multiplied, can hardly shift the balance of global power in the labor movement's contest with capital. Unless the set of new national connections includes a broader range of countries, its impact on labor's global architecture will be minimal.

A broader look at the USW show how an expanded set of transnational alliances connecting a range of countries can emerge, in spite of the traditionally ambivalent relation of a rich country tradable goods union. The USW defined its anti-globalization agenda by dumping imported steel into the harbor in Seattle in 1999 and welcomed the Bush administration's attempts to impose quotas on Brazilian steel imports. Yet, its support for Liberian rubber workers was also consistent with a history of transnational initiatives. The Steelworkers' successful fight against Marc Rich and the management of Ravenswood Aluminum is one of the most storied transnational campaigns of recent memory (see Juravich and Bronfenbrenner, 1999). ${ }^{?}$

Even more relevant from the point of view of this analysis, is the USW's alliance with the Mexican mineworkers union, the SNTMMSSRM (Sindicato Nacional de Trabajadores Mineros, Metalúrgicos, Siderúrgicos y Similares de la República Mexicana), known as the Mineros (see Davis, 2012). The USW-Minero relationship not only illustrates the USW's openness to transnational alliances but also show how increased receptivity to transnational alliances by formerly corporatist unions in the South can be a critical complement to transnationalist initiatives from the North. 
Faced with government repression in the iconic 1989 strike at the Cananea copper mine, Mexico's Mineros were still not ready to make alliances with U.S. unions part of their strategy. By 2005, a series of virulent attacks from the Mexican state had changed their minds. They signed a strategic alliance with the USW, affiliated with both the IMF (International Metalworkers Federation) and the ICEM, and held a one-day solidarity strike to support of a USW strike at the U.S. subsidiary of Grupo Mexico (Davis, 2012: 506). By the following year, government prosecutions had forced Mineros President Napoleon Gomez Urrutia into exile in Canada where he relied on support by the USW. In 2010, USW President Leo Gerard and Gomez Urrutia announced a commission to explore the formation of a single North American Union. The single North American union has not materialized, but if it were to become reality it would add roughly 200,000 Mineros to the roughly 800,000 USW members in the U.S. and Canada to create one of the largest unions in the hemisphere.

If the USW-Mineros alliance further illustrates the potential benefits of the new U.S. transnationalism for unions in the South, the support that USW received as a result of its membership in the Gerdau Workers World Council (GWWC) is one of the best examples of how U.S. unions can become the beneficiaries of reverse whipsawing.

The initial impetus for the GWWC was the aggressive national and global expansion of Brazil's largest private steel producer, Gerdau, which by 2003 had become the fourteenth largest steel producer in the world with subsidiaries throughout North America and in Europe (Gray, 2009: 89). The Metalúrgicos in Brazil, affiliated with the Central Única dos Trabalhadores (CUT), realized that they could not defend their rights and wages against Gerdau on the basis of struggles by individual locals against the managements of individual plants. They first built a national network of Gerdau workers. Exchanges with Canadian USW workers funded by the Canadian 'Steelworkers Humanity Fund' starting in 1997 began a transnational initiative. In 2003, Gerdau workers from Brazil, Argentina, Chile, Uruguay, Canada and the U.S. met to discuss the possibility of building a transnational network (see Gray, 2009: 81-92).

At the same time, steel production in the U.S. was moving to mini-mills run by labor-hostile firms in the right-to-work states of the American South, undermining the USW's ability to organize or even maintain existing contracts. The USW's problems and the efforts of the Gerdau network converged in 2005 when contract talks at a Gerdau-owned plant Beaumont, Texas ended in a lockout after Gerdau subsidiary Ameristeel demanded cutting vacations, overtime pay, and seniority rights as part of their 'last best offer.'

The USW realized that a comprehensive campaign would have to extend to Gerdau's home base to be effective and the CUT Metalúrgicos were prepared to offer solidarity. Without trying to recapitulate the story of a long and dramatic campaign (see Gray, 2009: 98-122), suffice to say that, pressured at home in Brazil as well as by a global campaign based on the GWWC network, the Gerdau management in Brazil finally decided that the hard-line anti-labor approach of Ameristeel managers in the U.S. was counter-productive. In 2007 the USW was able to negotiate contracts at the plants where it had been locked out. ${ }^{10}$

Another traditional tradable goods union, the UAW, is currently pursuing an even more interesting variation on the 'reverse whipsawing' strategy. In 2010, the UAW's new President Bob King made unionizing foreign-owned auto assembly plants (known as 'transplants') in the U.S. South his primary auto industry goal. ${ }^{11}$ It made sense. Unless it can unionize these plants, the UAW is condemned to watching the number of unionized U.S. autoworkers shrink. The problem with King's initiative was that the project looked like 'mission impossible.' Though unionized in their home countries, foreign auto firms were happy to take advantage of the anti-union environment of 
the American South. They dampened workers' economic incentive to organize by offering good wages relative to prevailing local standards.

King's response to this mission impossible was multi-pronged. At VW's (Volkswagen's) plant in Chattanooga, Tennessee, the UAW developed a strategy based on traditionally structured reverse whipsawing, relying on the institutionalized power that IG Metall had built in its German base. Because a union-inclusive works council system has become an integral part of VW's modus operandi around the world and by U.S. law requires a union, IG Metall and the UAW were able to persuade VW to remain neutral in the union election. ${ }^{12}$

The result was a confrontation of transnational economic leverage and national political culture. The company may have been neutral, but local politicians in Tennessee were vociferous in their condemnation of the UAW as 'foreign' to the South and of Volkswagen as 'un-American' in its willingness to accede to a vote. In the end, reverse whipsawing almost worked, but not quite. The UAW lost the election by a margin of 86 votes (712 to 626), much closer than the results of previous, less transnationally supported, efforts to organize transplants in the South, but still a defeat and an indication of the limits of the capacity of transnational strategies to shift the local balance of political forces within the United States. ${ }^{13}$

King's other transnational strategy for organizing transplants was more innovative, though equally 'mission impossible'. He targeted the Nissan plant in Canton, Mississippi, where ordinary Nissan workers were likely to be in the upper half of the state's income distribution and an economistic argument for the union was not likely to get traction (See Greenhouse, 2013). Instead, the campaign focused on the union as a vehicle for giving the workers a voice in their work lives. The UAW framed the quest for a voice on the job as the next step toward completing Mississippi's unfinished civil rights agenda, which resonated with the plant's mostly African-American workforce. With this framing, the campaign gained the support of the local National Association for the Advancement of Colored People (NAACP) (see Compa, 2013).

As compelling as the campaign might be locally, the UAW realized that as long as the contest was fought only in Canton, it would provide little leverage vis-à-vis Nissan's global management. When Nissan workers rallied at Tugaloo College at the beginning of 2013, Vagner Freitas, the President of Brazil's CUT, was among those in attendance. Bringing CUT's President to Canton was not just an exercise in 'labor diplomacy'. In Nissan's global strategy for building market share, Brazil was a crucial element, making Brazil strategically important for the UAW as well. Winning in the U.S. South depended on building a durable alliance in the Global South.

Brazil was the fourth largest auto market in the world and one that was growing more rapidly than markets in the global North. ${ }^{14}$ It was a market in which Nissan saw an opportunity to expand its market share. If the UAW could make a credible threat to disrupt Nissan's planned expansion in Brazil part of its bargaining hand, the cost of preventing unionization in Canton would increase dramatically.

Changing the political environment for Nissan in Brazil would require more than a campaign garnering support for a strike. It would require a long-term investment in creating institutional links to the Brazilian labor movement and awareness in the Brazilian media and popular culture of the anti-union stance of transplants in the U.S. South. The UAW invested in two organizers in Brazil. Bob King spent a week in Brazil in mid-2012 to mark the opening of the UAW's Brazil office, gave a speech at the CUT national congress, and met with the President of the Chamber of Deputies Marco Maia (also a former Metalúrgico). Four months later the UAW had a booth at the auto show in São Paulo to build relations with the local media. 
King's message to Brazil was that U.S. unions admired their Brazilian counterparts and had a great deal to learn from them, that the declining power of unions in the U.S. was making the U.S. working class evermore precarious, and that transnational alliances had to be part of the response. Brazilian Labor leaders were impressed that the UAW had started by building ties and were therefore more sympathetic to the campaign. The civil rights emphasis of the Mississippi campaign also resonated in Brazil (see Donizetti, 2013). When the CUT announced its 2013 accord with the AFL-CIO, 'fighting anti-union practices at the Nissan Plant in Mississippi' was the single concrete joint action highlighted. CUT metalworkers joined with their rival federation, Força Sindical around support for the Mississippi Nissan workers. ${ }^{15}$ In October of 2013, former Brazilian President Luiz Inácio 'Lula' da Silva wrote a letter to Nissan President Gohsn saying that while he considered Nissan 'to be an outstanding global company' that had 'good relationships with unions in Brazil and other countries,' he was 'deeply concerned about the anti-union campaign that Nissan is conducting in the U.S.' and expected 'remedial action' (Lula, 2013).

Creating a local union with several thousand workers in Mississippi would arguably be just as consequential for that local political economy as establishing an independent union for 5,000 rubber plantation workers was to the local political economy of Liberia, but it remains to be seen whether King's strategy can succeed. Even if Brazilian pressure on Nissan is effective, the ferocity of local political opposition will be commensurate with the magnitude of the effect of unionization. Succeed or fail, the initiative is still a signal example of a traditional American industrial union's awakening to the essential role that global alliances must play in its domestic survival strategy.

Since the UAW, like the USW, is a union whose traditions and political culture are rooted in a classic tradable goods industry, these examples have implications beyond pointing to an increased openness to transnational alliances on the part of U.S. labor. Both examples suggest old arguments that conflicts over the geographical distribution of jobs in tradable goods industries undermine the possibility of transnational initiatives should be revised.

\section{The Transnational Articulations of the 'Rising South'}

Just as Brazil plays a key role in Nissan's vision of its global profits, the major countries of the Global South are central to capital's general quest to expand global profits. These countries are not just 'dynamic major economies with growing political influence' (UNDP, 2013); they are arenas of socio-political contestation in which national labor struggles are intertwined with transnational strategies. Brazil is the obvious case for exploring the potential for positive interactions between such terrains and labor's global architecture. There are two questions here. First, what role might labor movements in the major countries of the Global South play in building labor's global architecture? Second, and conversely, what kind of role might a more effective global labor architecture play in provoking positive inflections in the evolution of these national terrains?

Brazil's role in supporting the nascent efforts of U.S. unions to build transnational alliances has already been highlighted, but the bulk of Brazil's transnational alliances have involved European unions, enterprise networks, international framework agreements and GUFs closely tied to European unions. Brazil's initial transnational alliances were built around struggles with the Brazilian military regime over trade union rights in the 1970s (Anner, 2011: 125). For example, IG Metall unionists working at Volkswagen in Germany supported the efforts of Brazilian Volkswagen workers to gain basic trade union rights in Volkswagens' Brazilian plant.

Later, economic struggles came to the fore. Brazilian trade union leaders learned German and became active participants in the worldwide works councils of the German auto companies, both 
Volkswagen and Daimler. ${ }^{16}$ This work bore fruit in 2001 when CUT leadership used its German connections to trump the intransigence of the subsidiary managers in Sáo Paulo, set up direct negotiations at VW headquarters in Wolfsburg, get production of a new model located in Brazil, and mitigate planned layoffs (Anner, 2011: 128). German-Brazilian transnational alliances have also resulted in solidarity actions to prevent the company from compensating for production losses created by strikes in Germany by increasing overtime in Brazil (Anner, 2011: 130-131).

Alliances with other unions and participation in worldwide works councils have been complemented by the use of International Framework Agreements (IFAs/GFAs) designed to bind operations around the world to standards accepted by the parent company in its home base. Like worldwide works councils, IFAs are a characteristically European device. Framed in the most generic terms, IFAs are 'toothless' in the absence of complementary union power, but, in the context of local organization and transnational labor networks, they can be valuable tools (see Fitcher and Helsen, 2011; McCallum, 2013; Stevis and Boswell, 2007, 2008).

The Brazilian Metalúrgicos' use of the Daimler IFA signed in 2002 exemplifies the potential usefulness of IFAs. Because the Daimler IFA applies to suppliers as well as the subsidiary itself, the Metalúrgicos working at Mercedes in Brazil were able to turn it into an instrument for strengthening union power in less well-organized supplier plants by striking against IFA violations at suppliers and getting the Mercedes management to intervene on the side of enforcement (see Fichter and Helfen, 2011: 99-100).

Brazilian unionists have complemented broad collaborations with European Federations with building alliances within individual enterprises. The long history of collaboration between the Dutch Federation of Trade Unions (FNV) and the CUT is a good example. Working with the CUT's Instituto Observatório Social (Social Observatory), the FNV supported research on the compliance of multinational corporations with the core labor standards to which they claimed to adhere. It also supported the 'CUT-Multi' project ('Action Confronting Multinationals'), which was designed to build networks among all the unions (within CUT and outside it) organizing workers in a particular multinational corporation (Veiga and Jakobsen, 2011: 77-85). As of 2007 there were twenty-five of these networks in operation (Jakobsen, 2007: 154). While focused most intensely on the subsidiaries of Dutch companies (Akzo-Nobel, Phillips etc.), CUT-Multi extended to other multinationals with other origins as well. One of the most developed enterprise networks is the BASF (Badische Anilin- und Soda-Fabrik, a German Chemical Company) network, which extended throughout Latin America and was activated in support of the U.S. Steelworkers in the American South. In 2005, again with the FNV's support, the Observatório's enterprise research methodology shared with organizations in six other Latin American countries eventually creating the 'Latin American Network for Research on Multinational Companies' (REDLAT) (Veiga and Jakobsen, 2011: 92-93).

Brazil has also found that GUFs can play a useful domestic role. Global Union Federations must remain ostensibly neutral among the multiplicity of labor confederations that have sprung up in Brazil's relatively labor friendly environment. Consequently, GUFs can play an often-useful diplomatic role in negotiating broad campaigns. The Building and Wood Worker's International (BWI) 'Campaign for Decent Work in FIFA World Cup 2014' is a good example. It required forging a common campaign among construction unions affiliated with five different Brazilian confederations, something that would have been very difficult for CUT or any other individual Brazilian confederation to do. Likewise, Public Services International (PSI) often finds itself engaged in diplomatic negotiations among Brazilian unions affiliated in with different confederations that work in health and other service fields. 
Brazil shows how a favorable national terrain can both stimulate the articulations of transnational labor networks and benefit from them. It shows how a well-organized labor movement can engage in both the confrontational campaigns associated with American labor's combative relation to intransigent companies and the institution-building focus associated with European unions. Brazilian labor's ability to engage in both types of strategies is a hallmark of its ability to become a central nexus for transnational labor networks.

Brazil offers a model for the gains to global labor that can accrue from the political empowerment of labor in major countries of the Global South, but it also illustrates the useful role global infrastructure, both as support for campaigns within a national terrain and support for building connections between national labor movements. Connections based on one national political conjuncture or bilateral alliances must be complemented by multi-country networks and campaigns, which in turn require a more developed global apparatus than labor has been able to count on in the past.

\section{Connecting Multiple National Terrains}

Multinational corporate empires never limit themselves to connecting only two national markets. The global labor movement cannot afford to be content with bilateral connections either. National connections must eventually be embedded in broader structures if they are to exercise real power in a global economy. Labor must build its own version of global governance. Cross-border corporate campaigns, enterprise networks, IFAs, and GUFs are all forms that can link multiple national terrains, and their use has accelerated rapidly under neoliberalism (see Bronfenbrenner, 2007; Munck, 2010), a welcome change from the relative quiescence of the post World War II 'golden age of capitalism'.

Traditionally, the international union structures that should provide the organizational backbone of such a project have been underfunded by national unions, while still remaining beholden to richer unions in the North, primarily Europe (see Jakobsen, 2001). Have the hard times of neoliberalism provided sufficient incentives for national labor movements to invest sufficient resources in global union structures? Is there hope that these organizations will in turn become more effective at articulating the interaction of national labor movements? Skeptics will dismiss both possibilities, but they may be missing some promising 'green shoots'.

Global Union Federations (GUFs), the sectoral embodiments of the formal global union movement, have evolved from their days as 'International Trade Secretariats.' At the beginning of the post-World War II 'golden age of capitalism,' the International Trade Secretariats were tiny and sector-specific. The expansion of these global sectoral organizations stands in contrast to the relative stagnation of union membership at the national level. They are playing a more active role, not just in favorable terrains like Brazil, but in multi-country campaigns as well. ${ }^{17}$

While union densities have fallen in most countries around the world, with membership falling in absolute terms in some countries, the membership and number of affiliates of GUFs continued to grow until they were five times their mid-twentieth century size. ${ }^{18}$ Size is not necessarily an indicator of strategic acumen or mobilizational effectiveness, but it does make reach and resources available for strategic initiatives. Today's GUFs are huge. IndustriALL, the merged industrial global union, has 50 million members and 800 affiliated national unions around the world. The two large service sector GUFs - PSI and UNI - have in combination 40 million members and 1,500 affiliated unions. 
Along with the GUF's new size and scope has come increased interest in forcing companies to sign International Framework Agreements (IFAs or GFAs), like the Volkswagen and Daimler IFA's discussed in the Brazilian case. The first IFA was signed in 1988; at the turn of the millennium there were still only eight; by 2006 there were 55 (Stevis and Boswell, 2007: 112-113). It has proved almost impossible to get U.S.-based companies to sign IFAs (see Fitcher and Helfen, 2011; Stevis and Boswell, 2007, 2008), but the International Metal Federation's 2012 IFA with Ford suggests that the new transnationalism of U.S. may include pushing for IFAs with U.S.-based multinational firms (see IMF, 2012).

Since IFA's have jurisdictions that are as multinational as the companies and Global Union Federations that sign them, the real issue is whether they can diffuse gains won in environments where labor is stronger to less favorable national terrains. Stevis and Boswell (2007: 175) argue that IFAs' 'chances for empowering the organized and organizing the unorganized will depend largely on whether they become integrated in global cross-border strategies, such as comprehensive campaigns.' In short, they point to a combination of European-style institution building and U.S.-style corporate campaigns as a way of turning IFAs into a more potent tool for the global labor movement.

The best case study of how an IFA can be integrated into a multi-country corporate campaign is the G4S campaign to organize security guards. The G4S campaign is generally acknowledged as the early $21^{\text {st }}$ century archetype of a global corporate campaign. It shows how combining IFAs and global campaigns depends on building a corresponding organizational architecture that can combine the on-the-ground efforts of a diverse set of national unions with the worldwide negotiating scope of a Global Union. It underlines that global strategies are as important in the now globalized service sector as in manufacturing. And, it provides valuable insights into the way in which national terrains shape and can be shaped by global campaigns.

Jamie McCallum's (2013) analysis of the G4S campaign gives us a theoretically provocative picture of how the campaign worked at both global and national levels. The key actors in McCallum's analysis include Union Network International (UNI), the largest of the service sector GUFs, SEIU, a prime U.S. practitioner of aggressive corporate campaigns, the South African Transport and Allied Workers Union (SATAWU), the Indian National Trade Union Congress (INTUC), and Center of Indian Trade Unions (CITU).

As G4S's largest market, India was a crucial element in the global campaign; South Africa and a number of other countries in the Global South played an important role as well. However, the origins of the G4S campaign were not in India or South Africa, but in SEIU's conviction that only a global campaign could crack the barriers that were preventing it from organizing the most important employer of security guards in the United States. Key parts of the SEIU's leadership apparently decided, as Harold Myerson (2009) put it, 'If you want to organize security guards in Chicago, you have to organize the whole damn planet.'

The origins of the new transnationalism in this service sector case are remarkably similar to the dynamics already described in the cases involving auto and steel. Just as the USW and the UAW had to find global strategies to confront global capital's power over its members in the United States, the SEIU Property Services division found itself facing employers that were no longer local, or even national, but global. When the British-based G4S acquired Wackenhut, one of the largest U.S. employers of security guards, the impetus for mounting a global campaign in order to organize security guards in the U.S. was set in motion.

The logic of building transnational partnerships was, however, quite different in the G4S case than in the case of the UAW and USW campaigns. No single country market was sufficiently 
important to force G4S to negotiate. The campaign had to be fought on multiple terrains, but by the same token it did not necessarily require allies that were individually powerful. Working through UNI, SEIU constructed a Lilliputians vs. Gulliver strategy in which unions from multiple countries, none of them particularly powerful in their own national contexts, converged to force the corporate Gulliver to negotiate. Unions in an impressive array of countries became involved, ranging from countries in the North, like U.S. and Britain, to major countries in the South, like Indonesia, India and South Africa, to smaller countries in the South like Malawi and Ghana.

The organizational centerpiece was UNI. Founded in 2000 and signing its first GFAs in 2001, by the spring of 2013 UNI had signed 48 global agreements, more than any other GUF. UNI's aggressive organizing stance is a direct consequence of both the support it has received from SEIU and the infusion of leadership with experience working on SEIU campaigns. Christy Hoffman, who came to UNI with extensive SEIU experience and became Deputy General Secretary in 2010, replacing UNI's retiring co-founder, Philip Bowyer, exemplifies the new generation of leadership. Turning a variegated set of national level unions into a collective power that could force G4S to sign an IFA depended on bringing UNI's encompassing organizational structure to bear on an integrated multi-country organizing campaign. Thus, UNI's role exemplifies the possibilities for transforming GUFs into vehicles for multi-country organizing campaigns.

A global campaign was the 'sine qua non' of bringing G4S to the table, but the campaign had to be fought on disparate national terrains. Each national campaign reflected local political contexts and local union histories. At the same time, being part of a global campaign had an impact on the national unions that were involved. McCallum's analysis of South Africa and India shows how national politics can turn a global campaign into two very different sorts of campaigns in different national contexts as well as how participation in a global campaign can reshape the strategies of national unions.

In South Africa, the global campaign fostered the revitalization of the national partner union, SATAWU (McCallum 2011, 2013: chapter 4). UNI staffers working in South Africa brought an emphasis on organizing that was instrumental in helping SATAWU transform itself from a servicing union into an organizing union. SATAWU's participation in the campaign helped stimulate the organization of an additional 3,000 security guards, increasing the number of organized security guards by $40 \%$.

The local effects of the eventual signing of a Global Framework Agreement by G4S's top management in London also vindicate the potential of GFAs. Far from being an abstract piece of global paper, the GFA invigorated local organizers, giving them a sense of authority that trumped the recalcitrance of local managers. McCallum (2013: 118) quotes one local organizer as saying, 'This is my copy of the global agreement. It's like a bible, man. When management tells me to get out, I show them this [the GFA]. When workers are afraid to join, I show them this. When people tell me we don't have the right, I point to this.'

While the scale of South Africa is too large to claim a nationally transformative effect comparable to the organization of the Firestone workers in Liberia or the Russell victory in Honduras, the national effects of this global campaign illustrate how global mobilization can contribute to union revitalization at the national level, even in major countries of the global South.

India proved to be a harder terrain for building transnational alliances. India's patchwork of politically divided union confederations made constructing a unified national campaign as challenging as constructing a campaign of continental scope in Africa or Latin America. UNI's organizers in India ended up trying to build an alliance between the Communist Party (Marxist)-led Congress of Indian Trade Unions (CITU) federation in West Bengal and the Congress affiliated 
Indian National Trade Union Congress (INTUC) in South India. Problems and conflicts abounded and the overall campaign was only a limited success at the national level.

Despite its problems, two aspects of the campaign in India merit special mention. First, although ultimately unsuccessful, the Indian Security Workers Organizing Initiative (ISWOI), which was set up by the G4S campaign, was one of the first efforts of its kind to bridge the divide that separated the CITU and INTUC. Second, in a testimony to the power of the local political context, the campaign in India developed its own distinctive strategy, consistent with the strategies of other quite different organizing campaigns in India, such as SEWA (Self-Employed Women's Association) (Agarwala, 2013). Instead of making demands on the company directly the campaign ended up working for 'nationwide legislation that could raise standards for security guards across the industry, effectively extending aspects of the global agreement into India's political arena.' (McCallum, 2013: 138).

The reciprocal relation between national and global labor mobilization is clear in the G4S campaign: national terrains shape the character and effectiveness of global campaigns, but global campaigns can also reshape the contours of national terrains. The campaign underlines once again the strategic importance of the Global South. Without the multinational mobilization across a range of countries in the Global South and the compelling evidence of degraded wages and working conditions that these national movements brought to the siege of the global headquarters in London, it is unlikely that global management would have succumbed. Finally, the G4S campaign brings to the fore once again the blend we saw in Brazil: a European-style utilization of the Global Union structures and global framework agreements combined with an aggressive, confrontational American-style corporate campaign.

\section{Transnational Connections and National Labor Movements in the Neoliberal Era}

The idea that new sorts of labor transnationalism emerged in the neoliberal era is not fanciful. Neoliberalism has not prevented the emergence of new connections among national labor movements. One source of new possibilities was the changing positions of national terrains in the global political economy. Another was the construction of new strategies and structures at the global level. Having explored these possibilities in some detail, it is time to consider their current and future implications for the global labor movement.

I have focused particularly on how shifting national positions resulted in increased participation in transnational alliances in two countries: the declining United States and an emerging Brazil. But, the ramifications of these shifts go beyond the changing strategies of these two national labor movements. They involve a kaleidoscopic array of cases touching on a range of countries in both North and South.

In the U.S. case, unrelentingly anti-labor national politics have generated new incentives for unions to look for transnational alliances. However partial, this shift created opportunities for other national movements. The victories of the Honduran textile workers over Russell athletics and the Liberian Plantation workers over Bridgestone-Firestone show the utility of U.S. labor's openness to transnational initiatives, at least in the case of small, poor countries where local capital is dependent on the U.S. economy. SEIU's organizational investment in the G4S campaign illustrates how a more transnational orientation in the U.S. can contribute to broader campaigns. Despite its declining fortunes at the national level, U.S. labor still commands enough power and resources to be a useful ally for other movements. 
Brazilian labor learned the value of transnational alliances early, during its struggles against the military regime. The globalization of Brazilian-based capital added to the incentives created by the longstanding predominance of transnational corporations to make the Brazilian labor movement even more open to making connections with other national labor movements. Openness to transnational strategies, combined with political and organizational capacities built up over decades of struggles, made the Brazilian labor movement a valuable ally. This was particularly clear in the case of the Gerdau Workers World Council support for the USW in the Ameristeel case, and also applied to the potential effects of Brazilian support in the UAW's Mississippi Nissan campaign. But, Brazil's role in South-South networks - including the GWWC and REDLAT (Latin American Network for Research on Multinational Companies ) is also important.

Together, these cases argue for an expanded vision of the possibilities for 'reverse whipsawing' (see fn. 5). The traditional examples of reverse whipsawing are there: national labor movements in the South gain leverage by building ties with labor in the North; both Brazilian and U.S. unions gain leverage by making connections to more firmly institutionalized unions in Europe. But, the BrazilU.S. cases show that reverse whipsawing in which strength in the South can redound to the benefit of labor in the North.

At the same time, these cases illuminate the interaction of global campaigns and historically rooted national political contexts. National political contexts remain the single most powerful determinant of movement fortunes, but they are also malleable. They are not just independent variables' that shape possibilities for transnational action. They can also be reshaped to labor's advantage by global campaigns. Transnational efforts can catalyze victories and invigorate labor movements at the national level - in major ways in small countries, as Honduras and Liberia show, and at a more specific sectoral level in larger countries, as the G4S campaign's revitalizing effect on SATAWU illustrates. Brazil shows how a favorable national terrain can both stimulate the articulations of transnational labor networks and benefit from them.

The development of new connections among national labor movements in the neoliberal era was complemented by the construction of new strategies and structures at the global level. Institution building strategies like IFA/GFAs, worldwide works councils and enterprise networks burgeoned. Multi-country organizing campaigns, which are the heart of the matter, cannot claim the same accelerating growth, but the G4S campaign illustrates the accumulation of expertise on how to organize multi-country mobilization. Global labor continued 'learning by doing' at the global level under neoliberalism. The emergence of hybrid strategies that combine what have typically been considered European strategies with what have typically been considered American strategies is a good example of learning by doing. Brazilian unions were deeply engaged with European models of organizing revolving around GFAs and Global Unions, but were also open to American-style campaigning in the Gerdau and Nissan cases. The G4S campaign was a hybrid that put the two modes together.

Overall, the erosion of labor's power at the national level across a range of countries has taken its toll, but the development of global connections and strategies still continues. ${ }^{19}$ The evolution of labor's global architecture has not been defined by the simple sum of the fortunes of its national parts. New national connections and global learning by doing have produced concrete results for workers across a range of countries. The persistent bubbling up of new examples of labor transnationalism under the aegis of the hostile neoliberal regime may not add up to a 'great transformation' of the global labor movement (Munck, 2002), but neither are they consistent with 'uncompromising pessimism' (Burawoy, 2010). Carefully tempered, always skeptical optimism is a reasonable response to the ambiguities of the evidence. 
What about implications for the future? Do the examples of labor transnationalism considered here represent an evanescent blip sparked by idiosyncratic conjunctures in the neoliberal period? Or, are similar initiatives likely to become robust features of labor's contestation with global capital in coming decades?

The circumstances that produced the multiplicity of campaigns described here are hardly idiosyncratic. They stem from the interaction of national terrains that are integral to the overall structure of the global political economy. At the same time, these transnational connections do not flow simply from national positions in the structure of the global economy. They depend on specific national histories. Sustaining and reinforcing the structures and strategies that have emerged at the global level depend on the support and engagement of national labor movements and are therefore also contingent on an aggregation of national political trajectories.

The projected effects of the 'rise the South' provide a good illustration of the importance of specific national political trajectories. On the one hand, there are good structural reasons to expect the South to continue to become more important to labor transnationalism. Brazil illustrates how a favorable national conjuncture can magnify the general effect. Yet, even in the case of Brazil, it can't be assumed that the future will be an extension of past trends. Pessimistic analysts would argue that Brazilian labor's current international role represents an apogee unlikely to be sustained, either because CUT has lost the militant vision that was fundamental to both its domestic political role and its internationalism (e.g. Sluyter-Beltrão, 2010) or because Brazilian labor as a whole is caught in a comfortable corporatist trap that will undermine willingness to invest energy in combative campaigns, whether national or global (e.g. Braga, 2012).

Considering the evolution labor movements in other major countries of the Global South, whose political trajectories seemed equally promising in the 1980 's but which have not come to play a role comparable to that of Brazil, further underlines the importance of specific national political trajectories. South Africa is a case in point. ${ }^{20}$ Despite continued calls for more active political role from within COSATU's (Congress of South African Trade Unions) ranks (see for example, Sikwebu, 2013), labor has been relegated in practice to being a junior partner in a political alliance whose agenda increasingly diverges from the priorities of COSATU's rank and file.

In short, the ability of major labor movements in the Global South to make key contributions to the overall architecture of the global labor movement is a potential contingent on national political trajectories. It is possible that future political shifts in other countries of the Global South - anywhere from South Africa to Korea - might expand possibilities for building transnational articulations. But, it is also possible that the Brazilian labor movement might become more fractious and less transnationally engaged. The future evolution of the global political economy is likely to present labor movements in the Global South with opportunities to play a large role in labor transnationalism, but whether these opportunities can be seized will depend on national political trajectories. Labor can play a role in shaping these trajectories but it cannot determine them.

A similar point can be made in relation to the shift toward transnationalism in the U.S. labor movement. I have argued that the neoliberal decline of the U.S. has had the effect of pushing the U.S. labor movement toward a new transnationalism, but again, the effects of declining hegemony should not be taken as generic. European labor movements had a better record than U.S. unions for contributing to transnational efforts during the ascendant phase of American hegemony. As the examples of German solidarity efforts in the auto industry in both Brazil and the U.S. illustrate, this tradition continues. Europe's declining $21^{\text {st }}$ century fortunes do not however, appear to have stimulated shift in the direction of increased transnationalism comparable to the one that I have argued occurred in the United States. In short, we cannot assume that economic decline and 
national political climates more hostile to labor will necessarily push labor in the North to be outwardly facing.

Nor is the connection between declining hegemony and increasing labor transnationalism in the United States necessarily linear. Accelerating decline could undermine the capacity of U.S. labor to be a useful transnational ally. It might also provoke an inward turn, particularly if current transnational efforts do not bear fruit for U.S. workers.

The biggest source of uncertainty with regard to the future of labor transnationalism comes not, of course, from the United States but from the other side of the equation of shifting hegemony. If China's rising hegemony were to result in a global projection of the Chinese party-state's very effective repression of independent workers' organizations, prospects for the global labor movement would be grim. In this dystopian scenario, the hostile neoliberal regime could appear in retrospect not to have been the apogee of anti-labor politics but to have been global labor's last 'window of opportunity'.

There are no guarantees that the national connections developed under neoliberalism will not be eroded or reversed by negative political change in national arenas or shifts in the hierarchy of national power that structures the global political economy, but persistence of an opportunity set roughly similar to the one offered labor by the neoliberal era is a reasonable projection. Given this, it makes sense to focus on learning what we can from the experiences of recent decades about the dynamics that shape labor's global architecture.

Inability to provide clear predictions of future trajectories does not detract from the value of reflecting on articulations among national labor movements over the last twenty years as a means of understanding the evolution of labor's global architecture. Nor should uncertainty regarding future trends distract from the implications of focusing on connections among national labor movements for the analytical strategies employed in global labor studies.

Pessimistic theories of labor's demise at the hands of neoliberalism need to be reconciled with optimistic theories of the new labor transnationalism. Integrating analysis of interactions among national labor with analysis of both what is going on within national terrains and what is going on at the global level is a way of doing this. A theory of the global labor movement that focuses too exclusively at the global level will always be partial and misleading. Nor should the attention paid to national building blocks be limited to chronicling ways in which national differences can subvert transnational solidarity. The potential for positive synergies created by national difference deserves equal attention. Investigating the variety of ways in which national labor movements can connect with each other, positive as well as negative, is a necessary foundation for better theories of labor's evolving contestation with global capital.

\section{NOTES}

1. This article has been in the works for long enough to accumulate more debts that I can feasibly acknowledge here, but let me at least mention a few of those who have contributed. The article benefitted fundamentally from the knowledge, ideas and suggestions of Mark Anner, Jessica Champagne, Eli Friedman, Kjeld Jakobsen, Carolyn Kazdin, Robert Lawson, and Jamie McCallum, who participated in the Workshop on 'New Strategies For Building Transnational Labor Solidarity' held at Brown University's Watson Institute for International Studies in the fall of 2012. Katy Fox-Hodess and Pablo Gaston provided research and 
editorial assistance along with their owns insights. Two anonymous reviewers for this journal provided key restructuring suggestions on an initial submission.

2. For more some more recent analyses of the evolution of the new labor transnationalism see Evans (2010) Kay (2010), Munck (2010) and McCallum, J. (2013). Tarrow (2005) and Evans (2008) set the new labor transnationalism in the context of the general evolution of transnational social movements.

3. Like any era, neoliberalism combines a distinctive set of global economic rules, strategies, and structures with shifts in the geopolitical and economic hierarchy of nation states. For a general discussion of neoliberalism, see Evans and Sewell (2013). For those interested in situating the specific geopolitical logic of the neoliberal era in a general theoretical vision of how territorial logics of power interact with capital's global quest for profit, the work of Giovanni Arrighi (e.g. 1990, 1994, 1996) offers a powerful lens.

4. The 'belly of the beast' has been a favorite anti-imperialist appellation for the United States going back to José Martí. For a particularly relevant use of the term, see Cesar Rodriguez's (2007: 68) quote from Guatemalan unionist Homero Fuentes (also cited in Evans, 2010: fn. 30, p. 366).

5. See Evans (2010: 358). Starting with the classic corporate technique of 'whipsawing,' which uses locales where labor is weak to undercut the position of labor where it is strong, the term points to the possibility of doing the reverse -- expanding the power of workers overmatched in their own locale by connecting them with workers in locales where labor is stronger.

6. Hermanson had been a veteran apparel organizer with the International Ladies' Garment Workers Union (ILGWU) and had also worked in Latin America with the AFL-CIO Solidarity Center (see also Anner, 2013: 32).

7. Founded in Alabama in 1902, Russell joined Fruit of the Loom in Warren Buffet's Berkshire Hathaway empire in 2006.

8. For a full analysis of the complex composition of the networks involved see Rodriguez (2007). For a detailed insider's view of the Kukdong campaign, a successful earlier campaign that contributed to the 'institutional learning' that made the Russell victory possible, see Hermanson (2004).

9. The USW had already created one transnational union in 2008 by creating, jointly with the British 1.5 million member Unite the Union, to create a new entity called Workers Uniting.

10. It should be underlined that the GWWC is a South-South alliance as much as a South-North alliance, equally concerned about the effects of Gerdau's expansion into the rest of Latin America. A recent campaign against layoffs in companies acquired by Gerdau in Colombia is an example. 
11. While it is legitimate to link the UAW's strategy to King's presidency (and to his earlier influence as national organizing director), my attribution of specific strategic thinking is based only on my interpretations of the actions and public statements of King and the UAW, not personal communication.

12. 88 of VW's 104 plants around the world have works councils and U.S. law makes having a union a pre-requisite for having a works council. See Automotive News, 10/7/2013.

13. The UAW's 2001 effort to organize the Nissan plant in Smyrna, Tenneesse ended in a defeat by a 2 to 1 margin (Aschoff, 2014). Critics on the left were unimpressed by the improved margin, seeing the defeat as rooted in the UAW's inability to connect with rank and file workers (see Aschoff, 2014; Early, 2014).

14. From 2005 to 2011 , the Brazilian automobile market averaged $12 \%$ yearly growth compared to about $2 \%$ in the U.S. In fiscal 2011 Nissan sales almost doubled in Brazil (Nissan 2012 Annual Report, p. 16).

15. See joint op.ed. by leaders of Força and CUT metalworkers in the Folha de São Paulo, November 19, 2012 pg. 3. As Anner (2003, 2011) underlines, Força has traditionally been less internationalist than CUT, so this joint action was an important indicator of the UAW's deepening institutional ties in Brazil.

16. In 2002 there were Brazil had more members on the Volkswagen Worldwide works Council than any country other than Germany (see Rüb, 2002: 23).

17. Focusing on the conventional side of the global architecture forces me to neglect less formal multi-country organizations like SIGTUR (Southern Initiative on Globalization and Trade Union Rights), to which CUT, COSATU and the KCTU (Korean Confederation of Trade Unions) all belong and which require a separate analysis. See Webster, Lambert and Bezuidenhout, 2008; Evans, 2010.

18. These overtime comparisons are a bit imprecise since they refer only to affiliates of the International Confederation of Free Trade Unions (ICFTU) and the International Trade Union Confederation (ITUC). We lack data on the global sectoral organizations affiliated with the World Federation of Trade Unions (WFTU) and the World Confederation of Unions (WCL).

19. Some of the most interesting developments, which I have had to forego discussing here, involve ties between labor and other transnational social movements (see for example, Anner and Evans, 2004; Tarrow, 2005; Evans, 2008; Munck, 2010; Smith and Wiest, 2012).

20. On parallels between earlier phases of labor struggle in Brazil and South Africa, see Seidman (1994). 


\section{REFERENCES}

Agarwala, R. (2013) Informal labor, formal politics, and dignified discontent in India. Cambridge: Cambridge University Press.

Anner, M. (2003) 'Industrial structure, the state, and ideology: Shaping labor transnationalism in the Brazilian auto industry', Social Science History. 27(4): 603-634.

Anner, M. (2011) Solidarity transformed: Labor responses to globalization and crisis in Latin America. Ithaca: Cornell University-ILR Press.

Anner, M. (2013) 'Workers' power in global value chains: Fighting sweatshop practices at Russell, Nike and Knights Apparel' in Fairbrother, P., Hennebert, M.A., and Levesque, C. (eds.), Transnational Trade Unionism Building Union Power. New York: Routledge.

Anner, M. and Evans, P. (2004) 'Building bridges across a double-divide: Alliances between U.S. and Latin American labor and NGOs', Development in Practice. 14(1-2): 34-47.

Arrighi, G. (1990) 'The three hegemonies of historical capitalism', Review. XIII (3): 365-408.

Arrighi, G. (1994) The long Twentieth Century. Money, power, and the origins of our times. London: Verso.

Arrighi, G. (1996) 'Workers of the world at century's end', Review. XIX(3): 335-351.

Arrighi, G. (2007) Adam Smith in Beijing: Lineages of the Twenty-First Century. London: Verso.

Aschoff, N. (2014) 'Tennessee Car Sick Blues', Jacobin. February, [Online]. Available at https://www.jacobinmag.com/2014/02/tennessee-car-sick-blues/, [Accessed: 9 June 2014].

Automotive News. (2013) 'VW labor chief says Chattanooga model hinges on works panel,' (October 7), [Online]. Available at www.autonews.com/article/20131007/OEM01/ 131009897, [Accessed: 9 June 2014].

Braga, R. (2012) A política do precariado: Do populismo à hegemonia Lulista. São Paulo: Boitempo.

Bronfenbrenner, K. (ed.) (2007) Global unions: Challenging transnational capital through cross-border campaigns. Ithaca: Cornell University-ILR Press.

Burawoy, M. (2010) 'From Polanyi to Pollyanna: The False Optimism of Global Labor Studies', Global Labour Journal. 1(2): 301-313.

Chibber, V. (2007) 'Into the Fold: Labor's Incorporation into the Indian Political Economy', in Michael Goldfield and Debdas Banerjee (eds.), Labour, Globalization, and the State. London: Routledge. 
Compa, L. (in collaboration with the NAACP Mississippi State Conference). (2013) 'Choosing Rights: Nissan in Canton, Mississippi, and Workers' Freedom of Association under International Human Rights Standards', [Online]. Available at http://dobetternissan.org/ 2013/10/compa-report, [Accessed: 9 June 2014].

Davis, B. (2012) 'The Struggle of the National Mine, Metal and Steel Workers Union of the Mexican Republic', in Toledo, E.G. (ed.) La situació $n$ del trabajo en México: El trabajo en la crisis. Madrid, Spain: Plaza y Valdes.

Donizetti, P. (2013) 'Sonhos violados', Rede Brazil. [Online]. Available at www.redebrasilatual.com. br/revistas/81/trabalho/, [Accessed: 23 July 2013].

Early, S. (2014) 'VW to UAW: So Long Partner?' CounterPunch. (February 19), [Online]. Available at http://www.counterpunch.org/2014/02/19/vw-to-uaw-so-long-partner/, [Accessed: 9 June 2014].

Evans, P.B. (2008) 'Is an alternative globalization possible?', Politics \& Society. 36(2): 271-305.

Evans, P.B. (2010) 'Is it labor's turn to globalize? Twenty-First Century opportunities and strategic responses', Global Labour Journal. (1)3: 352-379.

Evans, P.B. and Sewell, W.H. (2013) 'Neoliberalism: Policy regimes, international regimes, and social effects,' in Hall, P and Lamont, M. (eds.) Social resilience in the neoliberal era. Cambridge: Cambridge University Press.

Fichter, M. and Helfen, M. (2011) 'Going local with global policies: Implementing international framework agreements in Brazil and the United States', in Papadakis, K. (ed.) Shaping global industrial relations: The impact of international framework agreements. New York: Palgrave Macmillan.

Graham, A. (2010) 'Massive victory for Honduran workers', Against the Current. 24(3): 21-22.

Gray, C. (2009) Metalúrgicos sem fronteiras: Building a global union at Gerdau. Unpublished MA Thesis, Cornell University.

Greenhouse, S. (2009) 'Labor fight ends in win for students', The New York Times. November 18.

Greenhouse, S. (2013) 'At a Nissan Plant in Mississippi, a Battle to Shape the U.A.W.'s Future,' The New York Times. [Online]. Available at http://www.nytimes.com/2013/10/07/business/ at-a-nissan-plant-in-mississippi-a-battle-to-shape-the-uaws-future.html, [Accessed: 9 June $2014]$.

Hermanson, J. (2004) 'Global corporations, global campaigns: The struggle for justice at Kukdong International in Mexico' Paper presented at Cornell University Conference on Transnational Labor Contention, April 9-11, 2004. 
International Labor Rights Forum (ILRF). (2005) 'Liberia: Firestone Sued Over 'Slave' Plantation', International Labor Rights Forum. [Online]. Available at http://www.laborrights.org, [Accessed: 4 December 2005].

IMF (International Metalworkers Federation) (2012) 'International framework agreement: Agreed upon social rights and social responsibility principles', Ford Motor Company and Global IMF I. Ford Global Information Sharing Network, April 25, 2012.

Jakobsen, K. (2001) 'Rethinking the International Confederation of Free Trade Unions and its Inter-American regional organization’, Antipode. 33(3): 363-383.

Jakobsen, K. (2007) 'Estratégia sindical frente às empresas multinacionais', Nueva Sociedad. 211(September-October): 145-159.

Juravich, T. and Bronfenbrenner, K. (1999) Ravenswood: The Steelworkers' victory and the revival of American labor. Ithaca: Cornell University-ILR Press.

Kay, T. (2010) NAFTA and the politics of labor transnationalism. Cambridge: Cambridge University Press.

Kazdin, C. (2012) 'What lessons from the USW's Transnational Solidarity Campaigns?' Presentation at workshop on 'New Strategies For Building Transnational Labor Solidarity' November $8^{\text {th }}$ Watson Institute, Brown University, Providence RI.

Lula [Luiz Inácio da Silva]. (2013) 'Letter to NISSAN' (October 10), [Online]. Available at http://dobetternissan.org/2013/10/former-brazil-president-lulas-letter-to-nissan, [Accessed: 9 June 2014]

MSN (Maquila Solidarity Network) (2010) 'Evangelina Argueta of the Maquila Solidarity Network speaks about her life as a union organizer', [Online]. Available at http://en.maquilasolidarity. org/node/964, [Accessed: 23 July 2013].

Mazur, J. (2000) 'Labour’s New Internationalism’, Foreign Affairs. Vol. 79. No. 1, pp. 79-93.

McCallum, J. (2011) 'Trade union renewal and labor transnationalism in South Africa: The case of SATAWU', WorkingUSA: The Journal of Labor and Society. 14(June): 161-176.

McCallum, J. (2013) Global unions, local power: The New Spirit of Transnational Labor Organizing. Ithaca: Cornell University Press.

Munck, R. (2002) Globalization and Labour: The New 'Great Transformation'. London: ZED Books.

Munck, R.P. (2010) 'Globalization and the labour movement: Challenges and responses', Global Labour Journal. 1(2): 218-232.

Myerson, H. (2009) 'Where are the workers?', The American Prospect. 20(2):20. 
Rodriguez-Garavito, C.A. (2007) Sewing resistance: Transnational organizing, global governance, and labor rights in the U.S.-Caribbean Basin apparel industry (1990- 2005). Unpublished Ph.D. Dissertation, Department of Sociology, University of Wisconsin, Madison, WI.

Rombaldi, M. (2012) Internacionalização do sindicalismo no Brasil: Um estudo sobre os setores metalúrgico e de telecomunicaçôes. Tese de Doutorado, Departamento de Sociologia, Universidade de São Paulo, São Paulo, Brazil.

Rüb, S. (2002) World works councils and other forms of global employee representation in transnational undertakings. Working Paper 55. Dusseldorf: Hans-Böckler-Stiftung.

Scipes, K. (2010) AFL-CIO's secret war against developing country workers: Solidarity or sabotage? Lanham, MD: Lexington Books.

Seidman, G. (1994) Manufacturing militance: Workers' movements in Brazil and South Africa, 19701985. Berkeley, CA: University of California Press.

Seidman, G. (2007) Beyond the boycott: Labor rights, human rights, and transnational activism. New York: Russell Sage Foundation.

Sikwebu, D. (2013) 'Notes from a Trade Unionist: Cosatu and its Affiliates as Democratising Agents or Contingent Democrats?' Rethinking Development and Inequality. Vol. 2: 63-67.

Silver, B.J. (2003) Forces of labor: Workers' movements and globalization since 1870. Cambridge: Cambridge University Press.

Sluyter-Beltrão, J. (2010) Rise and decline of Brazil's new unionism: The politics of the Central Unica dos Trabalhadores. Oxford: Oxford University Press.

Smith, J. and Wiest, D. (2012) Social movements in the world-system: The politics of crisis and transformation. New York: Russell Sage Foundation.

Standing, G. (2011) The Precariat: The new dangerous class. London: Bloomsbury Academic.

Stevis, D. and Boswell, T. (2007) 'International framework agreements: Opportunities and challenges for global unionism', in Bronfenbrenner, K. (ed.) Global unions: Challenging transnational capital through cross-border campaigns. Ithaca: Cornell University-ILR Press.

Stevis, D. and Boswell, T. (2008) Globalization and labor: Democratizing global governance. Plymouth: Rowman and Littlefield Publishing.

Tarrow, S. (2005) The New Transnational Activism. New York: Cambridge University Press.

UNDP (United Nations Development Program) (2013) Human Development Report: The rise of the South. New York: UN. 
Veiga, J.P.C. and Jakobsen, K. (2011) A cooperação laranja - verde amarela: A parceiria FNV e CUT. São Paulo, Brazil: CEDOC-CUT.

Waterman, P. (2001) 'Trade Union Internationalism in the Age of Seattle' Antipode. 33(3): 312336.

Webster, E., Lambert, R. and Bezuidenhout. A. (2008) Grounding globalization: Labor in the age of insecurity. Malden: Blackwell.

\section{GLOSSARY}

$\begin{array}{ll}\text { AFL-CIO } & \text { American Federation of Labor/Congress of Industrial Organizations } \\ \text { BASF } & \text { Badische Anilin- und Soda-Fabrik (German Chemical Company) } \\ \text { BWI } & \text { Building Workers International } \\ \text { CGT } & \text { Central General de Trabajadores (General Workers' Central) } \\ \text { CITU } & \text { Congress of Indian Trade Unions } \\ \text { COSATU } & \text { Congress of South African Trade Unions } \\ \text { CUT } & \text { Central Unica dos Trabalhadores (Unified Workers' Central) } \\ \text { FAWUL } & \text { Firestone Agricultural Workers Union of Liberia } \\ \text { FLA } & \text { Fair Labor Association } \\ \text { FNV } & \text { Federatie Nederlandse Vakbeweging (Dutch Federation of Trade Unions) } \\ \text { G4S } & \text { Group 4 Securicor } \\ \text { GFA } & \text { Global Framework Agreement } \\ \text { GUF } & \text { Global Union Federation } \\ \text { GWWC } & \text { Gerdau Workers World Council } \\ \text { ICEM } & \text { International Federation of Chemical, Energy, Mine and General Workers' Unions } \\ \text { ICFTU } & \text { International Confederation of Free Trade Unions } \\ \text { ICTU } & \text { International Congress of Trade Unions } \\ \text { IFA } & \text { International Framework Agreement } \\ \text { ILO } & \text { International Labour Organisation } \\ \text { ILGWU } & \text { International Ladies' Garment Workers Union } \\ \text { IMF (Union) } & \text { International Metalworkers Federation } \\ \text { INTUC } & \text { Indian National Trade Union Congress } \\ \text { ITUC } & \text { International Trade Union Confederation } \\ \text { KCTU } & \text { Korean Confederation of Trade Unions } \\ \text { NAACP } & \text { National Association for the Advancement of Colored People } \\ \text { NAFTA } & \text { North American Free Trade Agreement } \\ \text { NGO } & \text { Non-Governmental Organization } \\ \text { PSI } & \text { Public Services International } \\ \text { REDLAT } & \text { Latin American Network for Research on Multinational Companies } \\ \text { SATAWU } & \text { South African Transport and Allied Workers Union } \\ \text { SEWA } & \text { Self-Employed Women's Association } \\ \text { SEIU } & \text { Service Employees International Union } \\ \text { SIGTUR } & \text { Southern Initiative on Globalization and Trade Union Rights }\end{array}$


SNTMMSSRM Sindicato Nacional de Trabajadores Mineros, Metalúrgicos, Siderúrgicos y Similares de la República Mexicana (National Union of Mine, Metal, Steel and Allied Workers of the Mexican Republic)

UAW United Auto Workers

UNI Union Network International

UNITE Union of Needletrades, Industrial and Textile Employees

USAS

USW

United Students Against Sweatshops

WCL United Steelworkers

WFTU

World Confederation of Labour

WRC

World Federation of Trade Unions

Workers Rights Consortium

\section{BIOGRAPHICAL NOTE}

PETER EVANS is Professor of Sociology Emeritus at the University of California, Berkeley and a Senior Research Fellow at the Watson Institute for International Studies at Brown University. He also serves as serves as Secretary and Program Coordinator for the Research Committee on Labor Movements of the International Sociological Association. His earlier work focused on the comparative political economy of development in the global South. For the past several years he has been researching the efforts of social movements to mobilize transnationally to build a 'counterhegemonic globalization.' The global labor movement is a central focus in this work, as exemplified by this article and his 2010 article in the Global Labour Journal 'Is it Labor's Turn to Globalize?' [email: pevans@berkeley.edu] 